\section{EXPERIMENTAL STUDY ON THE IMPACT OF INTERMITTENT STRENGTHENING TRAINING ON ATHLETES}

\author{
ESTUDO EXPERIMENTAL SOBRE O IMPACTO DE TREINO INTERMITENTE DE FORÇA EM ATLETAS
}

ESTUDIO EXPERIMENTAL SOBREEL IMPACTO DE ENTRENAMIENTO DE INTERVALOS DE FUERZA EN ATLETAS

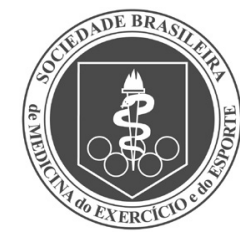

Original Article ARTIGO ORIGINAL Artículo Original

\author{
Hua Tian' (1D) \\ (Physical Education Professional) \\ 1. Hebi Polytechnic, Hebi, Henan, \\ China.
}

\section{Correspondence:}

Hua Tian. Henan, China. 458030

HuaTian376@163.com

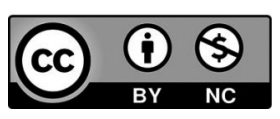

\begin{abstract}
Introduction: High-intensity interval training (HIIT) refers to multiple short-term high-intensity exercises. Objective: To study the impact of sprint interval training (SIT) on the athletic ability of elite rugby players. Method: 36 male rugby players from a sports college were selected. They were randomly divided into upper limb training (Group A), lower limb training (Group B), and routine training (Group C - control). Group C received routine training for six weeks. Groups A and B added SIT training based on Group C's upper and lower limb training. Results: After training, the maximum aerobic power (MAP) in Groups A and $C$ was significantly higher $(P<0.05)$, as well as the myeloperoxidase (MPO) of lower limbs in group B ( $P$ $<0.05)$. After completing 5 and 6 sets of SIT training, blood lactic acid (BLA) was lower in group $B(P<0.05)$. Parameters such as upper limb intermittent sprint exercise capacity and lower-limb aerobic exercise capacity did not significantly change compared with the same parameters before training $(P>0.05)$. Conclusions: Excellent male rugby players can improve their upper limb aerobic and lower limb intermittent sprint athletic ability by integrating different methods of SIT training into their daily training. Level of evidence ll; Therapeutic studies - investigation of treatment results.
\end{abstract}

Keywords: High-Intensity Interval Training; Football; Sports.

\section{RESUMO}

Introdução: Treino intermitente de alta intensidade (HIIT) se refere a múltiplos exercícios de alta intensidade num período curto de tempo. Objetivo: Estudar o impacto do treino de sprint intervalado (SIT) na capacidade atlética de jogadores de rúgbi de elite. Método: 36 jogadores de rúgbi do sexo masculino, de uma faculdade esportiva, foram selecionados. Eles foram divididos aleatoriamente entre treino de membros superiores (Grupo A), treino de membros inferiores (Grupo B), e treino de rotina (Grupo C - controle). O Grupo C recebeu treino de rotina por seis semanas. Os Grupos A e B acrescentaram ao treinamento de rotina um treino de SIT feito de acordo com o treino de membros inferiores e superiores realizado pelo grupo controle. Resultados: Depois do treinamento, o poder aeróbico máximo (MAP) dos Grupos A e C se mostrou significativamente mais elevado ( $p>0,05$ ), enquanto a mieloperoxidase (MPO) dos membros inferiores do Grupo B foi mais alta $(p<0,05)$. Parâmetros como capacidade de exercícios de sprint intermitente dos membros superiores e capacidade de exercícios aeróbicos dos membros inferiores não mudaram significativamente quando comparados antes e depois do treinamento ( $p>0,05)$. Conclusões: Jogadores de rúgbi de alto nivel podem melhorar sua capacidade atlética de sprint intermitente nos membros inferiores e de exercícios aeróbicos nos membros superiores ao integrar diferentes métodos de treinamento SIT em seu treino diário. Nível de evidência ll; Estudos terapêuticos - investigação do resultado de tratamentos.

Descritores: Treinamento Intervalado de Alta Intensidade; Futebol Americano; Esportes.

\section{RESUMEN}

Introducción: El entrenamiento de intervalos de alta intensidad (HIIT) se refiere a múltiples ejercicios de alta intensidad en un periodo corto de tiempo. Objetivo: Estudiar el impacto del entrenamiento de sprinten intervalos (SIT) en la capacidad atlética de jugadores de rugby de elite. Método: Fueron seleccionados 36 jugadores del sexo masculino de una facultad deportiva. Estos fueron divididos aleatoriamente entre entrenamiento de miembros superiores (Grupo A), entrenamiento de miembros inferiores (Grupo B) yentrenamiento de rutina (Grupo C - control). El Grupo Crecibió entrenamiento de rutina por seis semanas. Los Grupos Ay B agregaron al entrenamiento de rutina un entrenamiento de SIT hecho de acuerdo con el entrenamiento de miembros inferiores y superiores realizado por el grupo control. Resultados: Después del entrenamiento, el poder aeróbico máximo (MAP) de los Grupos A y C se mostró significativamente más elevado ( $p>0,05)$, mientras que la mieloperoxidasa (MPO) de los miembros inferiores del Grupo B fue más alta $(p<0,05)$. Parámetros como capacidad de ejercicios de sprint de intervalos de los miembros superiores y capacidad de ejercicios aeróbicos de los miembros inferiores no cambiaron significativamente cuando fueron comparados antes y después del entrenamiento ( $p>0,05)$. Conclusiones: Jugadores de rugby de alto nivel pueden mejorar su capacidad atlética de sprint de intervalos en los miembros inferiores y de ejercicios aeróbicos en los miembros superiores al integrar diferentes métodos de entrenamiento SIT en su ejercitamiento diario. Nivel de evidencia ll; Estudios terapéuticos - investigación del resultado de tratamientos.

Descriptores: Entrenamiento de Intervalos de Alta Intensidad; Fútbol Americano; Deportes. 


\section{INTRODUCTION}

High intensity interval training (HIIT) refers to multiple short periods of high-intensity exercise training, with intervals of low intensity or complete rest between each high-intensity workout. Generally, the duration of a single exercise session and intervals can vary from a few seconds to a few minutes. ${ }^{1}$ The significant feature of HIIT is high exercise intensity, which usually reaches or approaches the maximum exercise capacity of an individual in a short period of time. At the same time, due to the relatively short exercise time and small amount of exercise, the exercise load is not particularly large. At present, there are more and more domestic studies on HIIT. Compared with moderate intensity continuous training, HIIT can also produce good training effects and requires less exercise. $^{2}$ Studies show that in the early 1960s, Dang W used interval training method to guide the training of the Australian swimming team, and achieved remarkable results in the world swimming community at that time. Subsequently, coaches of various countries used interval training method to guide the training of periodic endurance events such as rowing, road cycling and short track speed skating, and achieved excellent results in each event. ${ }^{3}$ Duran I during the interval of training, the organs and muscles of the body are in a resting state, but the blood lactic acid in the blood is still being transported and oxidized, and the respiratory and cardiovascular systems still maintain a relatively high level of exercise. In this case, the body continues to accept higher load stimulation, the body can well improve the ability of acid resistance, effectively enhance the functional ability of respiratory and cardiovascular systems, so that the body's ability to fight fatigue has been enhanced. This ensures that athletes can continue to exercise for a long time even under high intensity conditions. ${ }^{4}$ After a short training period, the aerobic and anaerobic metabolic energy supply ability of male athletes were improved obviously. The operation process of the experiment was two weeks of high-intensity interval training, with two 15-second load exercises and a 45-second rest, followed by two 30-second fast running exercises and a 12-minute recovery. ${ }^{5}$

Therefore, in this study, elite male rugby players were taken as objects to observe the effects of SIT in different ways (upper limbs vs lower limbs) on aerobic and interval sprint ability in different parts of the body on the basis of regular training.

\section{METHOD}

\section{Research Objects}

Male rugby players of a certain university (all of whom are athletic) were selected and included in the following criteria: 1) All of them have participated in official international competitions (rugby World Cup, World Championship, Olympic Games, etc.); 2) Be healthy and free from cardiovascular and pulmonary diseases, metabolic diseases and motor system diseases; 3) No smoking or alcohol addiction; 4) No acute or chronic infection or sports injury occurred within 3 months; 5) Did not use weight control measures (diet, vomiting, laxative), did not take nutritional supplements and drugs. A total of 36 subjects met the above criteria and volunteered to participate in this experiment. Before the experiment, the subjects and their coaches should explain the research purpose and research process and sign the information Consent form. ${ }^{6}$

\section{Research Design}

Randomized in a controlled experimental design, subjects were randomly divided into upper limb training group, lower limb training group and conventional training control group, with 12 participants in each group. The subjects were used to get familiar with the experimental procedures (especially the use of upper and lower limbs power vehicles) for 3 days. The following tests were performed before SIT 6 weeks and
48 hours after the last training: 1) Body morphological indicators: height, weight, body composition, etc.; 2) Aerobic exercise ability test of upper and lower limbs (incremental load exhaustion test); 3) Intermittent sprint test of upper and lower limbs $(6 \times 10 \mathrm{~s}$ full pedal). All tests were completed at the same time (6:00-10:00 am) to avoid the interference of biological rhythm?

\section{Intermittent sprint exercise ability test}

The intermittent sprint ability of subjects was tested by high intensity interval sprint test. MONARK 891W and MONARK 894E bicycle dynamometer (Sweden) were used to test the anaerobic movement ability of upper and lower limbs according to the literature and the method established by the research group in the early stage. The resistance load was set as $5 \%$ of body weight (upper limb experiment) and 7.5\% of body weight (lower limb experiment). The subjects pedal with all their might for $10 \mathrm{~s}$, and the interval was divided into one group for 60 s. The subjects completed 6 groups in total. During the interval, they carried out active recovery, that is, they continued to exercise on the power vehicle. PPO and MPO are recorded by a computer connected to the dynamometer. Blood lactate (BLa) was measured using YSI.1500 blood lactate analyzer (USA) before and 3 min after the test. 3 min was chosen because the lactic acid produced by muscles immediately after high-intensity exercise exceeds the LEVEL of BLa, and the balance between the two has not yet been reached. Therefore, the time point of blood collection should be slightly delayed, about 1-5 min. In this study, 3 min can reflect the content of myolactic acid. ${ }^{8}$

\section{Statistical Analysis}

All data are expressed as "mean \pm standard deviation". SPSS 20.0 software package was used for statistical processing of the data, including baseline variables, body composition parameters and aerobic exercise ability parameters. One-way was used for inter-group comparison, and paired f test was used for intra-group comparison before and after the experiment. The time course variation of interval sprint performance was analyzed using repeated measures of variance. Statistical significance was defined as $P<0.05$. $^{9}$

\section{RESULTS}

General characteristics of subjects

All subjects completed all tests and training interventions. The characteristics of baseline variables before the experiment were shown in Table 1. There were no significant differences in body morphological parameters (age, height, weight, BMI, FFM, FM and PBF) and hemodynamic parameters (silent HR and blood pressure) between the three groups $(P<0.05)$, and there was no statistical significance in SIT training load between group A and group C $(P<0.05)$.

Table 1. Characteristics of subjects' baseline variables.

\begin{tabular}{c|c|c|c|c}
\hline Variable & Group A & Group B & Group C & The overall \\
\hline Age & $22.8 \pm 1.4$ & $22.9 \pm 1.4$ & $23.1 \pm 1.2$ & $22.9 \pm 1.3$ \\
\hline Height & $1.84 \pm 0.01$ & $1.84 \pm 0.01$ & $1.83 \pm 0.01$ & $1.84 \pm 0.01$ \\
\hline Weight & $83.3 \pm 1.2$ & $82.2 \pm 1.5$ & $83.3 \pm 0.9$ & $82.9 \pm 1.3$ \\
\hline BMI & $24.5 \pm 0.4$ & $24.3 \pm 0.4$ & $24.8 \pm 0.4$ & $24.5 \pm 0.4$ \\
\hline FFM & $74.0 \pm 1.4$ & $73.1 \pm 1.5$ & $74.2 \pm 1.2$ & $73.8 \pm 1.4$ \\
\hline FM & $9.2 \pm 0.7$ & $9.1 \pm 0.6$ & $9.1 \pm 0.7$ & $9.1 \pm 0.7$ \\
\hline PBF & $11.1 \pm 0.9$ & $11.1 \pm 0.7$ & $10.9 \pm 0.9$ & $11.0 \pm 0.8$ \\
\hline Heart rate & $60.8 \pm 4.3$ & $60.9 \pm 3.0$ & $61.4 \pm 3.5$ & $61.0 \pm 3.5$ \\
\hline Systolic blood pressure & $110.4 \pm 7.3$ & $109.3 \pm 8.5$ & $108.2 \pm 8.2$ & $109.3 \pm 7.8$ \\
\hline Diastolic blood pressure & $67.1 \pm 4.1$ & $71.2 \pm 4.7$ & $72.3 \pm 4.0$ & $70.2 \pm 4.7$ \\
\hline The training of & $5.9 \pm 0.6$ & $6.3 \pm 1.0$ & $6.4 \pm 0.6$ & $6.2 \pm 0.8$ \\
\hline SIT training load & $158.7 \pm 30.8$ & $162.6 \pm 33.7$ & & \\
\hline & & & &
\end{tabular}




\section{Changes in upper limb intermittent sprint motor ability}

There was no significant difference in PPO and MPO in upper limb $I H I S(P>0.05)$ (Figure 1 and 2). Compared with before IHIS, BLa after IHIS increased $(P<0.05)$, there was no significant change in BLa compared with before training $(P>0.05) .^{10}$

Changes in the movement ability of lower limb intermittent sprint

Before training, there was no significant difference in the IHIS parameters (PPO, MPO) of interval sprinting ability $(P>0.05)$. After training, PPO of group B showed no significant change compared with that before training $(P>0.05), M P O$ in IHIS experiment $S 5 \sim S 6$ was higher than before training $(P<0.05)$, BLa after IHIS was lower than that before training $(P<0.05)$; There was no significant change in the parameters of group $A$ and group $C(P>0.05)$.

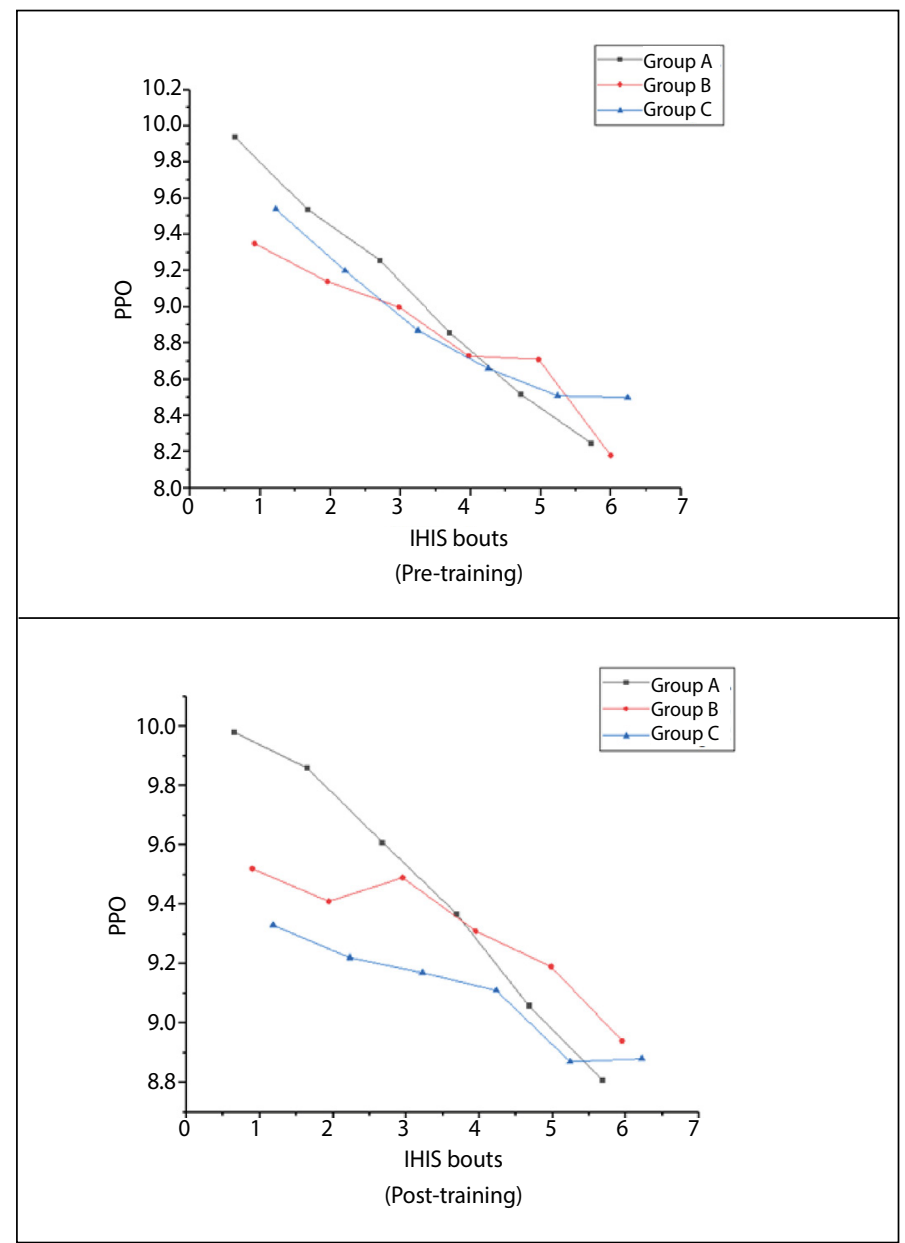

Figure 1. Changes of PPO in upper limb IHIS experiment.

\section{DISCUSSION}

In this study, aerobic exercise capacity of upper limbs was improved after different methods of SIT, which was manifested as increased MAP in group A and group C (and group A was higher than group C), VT and PVT in group $B$ during the upper limb incremental load exercise experiment. Improved aerobic capacity facilitates oxygen transport (that is, increased cardiac output) and oxygen utilization (increased arteriovenous oxygen difference) by working muscles (skeletal muscles engaged in exercise). However, the upregulation of MAP,VT, and PVT was not accompanied by a corresponding increase in V02max, which may be related to the short duration of the intervention, i.e., short-term training ( 6 weeks) had little effect on the cardiopulmonary system. For aerobic endurance sports,

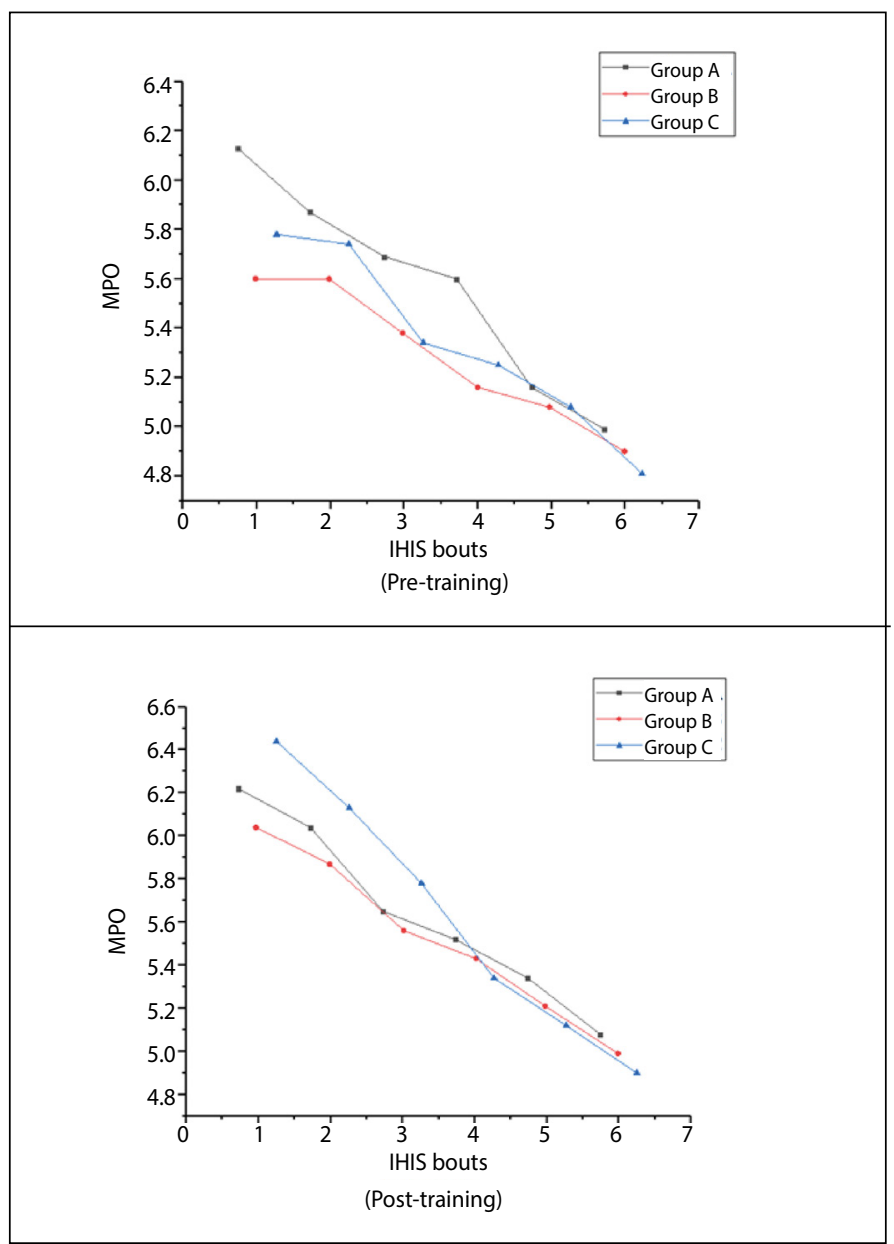

Figure 2. Changes of MPO in upper limb IHIS experiment.

the improvement of vital capacity is often related to the improvement of sports performance. In the process of high-intensity interval training, high-intensity exercise can stimulate the heart and respiratory function, resulting in sports adaptation. After several rest break, muscle and other tissues and organs is a short rest, in the energy storage stage, organ function also recovered, but due to the stimulation of movement did not completely eliminate, pulmonary ventilation and cardiac output and oxygen uptake will still remain within a certain amount of time at a higher level, the stimulation of cardiovascular system is not fully disappeared, training efficiency is higher per unit time. ${ }^{11}$

\section{CONCLUSION}

HIIT can effectively improve the lung capacity of football players, increase the concentration of $\mathrm{HB}$, and reduce the production of $\mathrm{BU}$ by reducing the amount of training, which is conducive to the improvement of athletes' physical function and positive training adaptation. Through systematic training, the performance of the athletes improved, and the performance of group A with HIIT improved more. The total amount of training for HIIT athletes is reduced, which can reduce the risk of sports-related injuries to a certain extent.

\section{ACKNOWLEDGMENT}

Key research and development and promotion special project (soft science research) of Henan Province in 2021, Project No.: 212400410246.

The author declare no potential conflict of interest related to this article 


\section{REFERENCES}

1. Amirazodi F, Mehrabi A, Amirazodi M, Parsania S, Rajizadeh MA, Esmaeilpour K. The Combination Effects of Resveratrol and Swimming HIIT Exercise on Novel Object Recognition and Open-field Tasks in Aged Rats. Experimental Aging Research. 2020;46(1):1-23.

2. Dosbaba F, Hartman M, Hnatiak J, Batalik L, Ludka O. Effect of home-based high-intensity interval training using telerehabilitation among coronary heart disease patients. Medicine. 2020;99(47):e23126.

3. Dang W, Jiang S, Zhang J, Wang F, Tao J, Wei X et al. Experimental and Modeling Study on the Effect of Shale Composition and Pressure on Methane Diffusivity. Energy \& Fuels. 2019;33(2):714-26.

4. Duran I, Martakis K, Stark C, Schafmeyer L, Rehberg M, Schoenau E. Effect of an interval rehabilitation program with home-based, vibration-assisted training on the development of muscle and bone in children with cerebral palsy - an observational study. Journal of Pediatric Endocrinology and Metabolism. 2020;33(8):1083-92.

5. MaY, Xiao M, Kermani B. Experimental Investigation of the Effects of Fluid's Physicochemical Characteristics on Piping Erosion of a Sandy Soil under Turbulent Flow. Geotechnical testing journal. 2020;43(2):436-51.

6. Hyakutake T, Sugita K, Ujifuku S, Sakurai R, Murakami R, Hayamizu Y. Experimental study on the effect of flow in microfluidic channel on bovine sperm navigation. Journal of Biomechanics. 2021;1 18(23):110290
7. Saidi O, Doré E, Maso F, Mack-Inocentio D, Walrand S, Pereira B et al. Acute effect of an intensified exercise program on subsequent sleep, dietary intake, and performance in junior rugby players. European Journal of Applied Physiology. 2019;119(9):2075-82.

8. Li Y, Chen X, Wu Y, Lu Y, Zhi R, Wang X et al. Experimental study on the effect of SiO_2 nanoparticle dispersion on the thermophysical properties of binary nitrate molten salt. Solar Energy. 2019;183:776-81.

9. Zeng Q, Duan Q, Li P, Zhu H, Sun D, Sun J. An experimental study of the effect of $2.5 \%$ methane addition on self-ignition and flame propagation during high-pressure hydrogen release through a tube. Internationa Journal of Hydrogen Energy. 2020;45(4):3381-90.

10. Cheng CX,Tian YJ, Wang F, Wu XH, Zheng JL, Zhang J et al. Experimental Study on the Morphology and Memory Effect of Methane Hydrate Reformation. Energy \& Fuels. 201933(4):3439-47.

11. Nguyen DD, Daneshfar R, Dehaghani AHS, Su CH. The effect of shear rate on aggregation and breakage of asphaltenes flocs: Experimental study and model-based analysis. Journal of Molecular Liquids. 2020;325(10):114861 